Relations industrielles

Industrial Relations

\title{
The Influence of Public Opinion in Labour-Management Relations and Dispute Settlement
}

\section{Stephen G. Peitchinis}

Volume 32, numéro 2, 1977

URI : https://id.erudit.org/iderudit/028788ar

DOI : https://doi.org/10.7202/028788ar

Aller au sommaire du numéro

Éditeur(s)

Département des relations industrielles de l'Université Laval

ISSN

0034-379X (imprimé)

1703-8138 (numérique)

Découvrir la revue

Citer cet article

Peitchinis, S. G. (1977). The Influence of Public Opinion in Labour-Management Relations and Dispute Settlement. Relations industrielles / Industrial Relations, 32(2), 268-274. https://doi.org/10.7202/028788ar

Tous droits réservés @ C Département des relations industrielles de l'Universite Laval, 1977
Ce document est protégé par la loi sur le droit d'auteur. L'utilisation des services d'Érudit (y compris la reproduction) est assujettie à sa politique d'utilisation que vous pouvez consulter en ligne.

https://apropos.erudit.org/fr/usagers/politique-dutilisation/ 
Enfin, il faut bien se rendre compte que le mouvement syndical ne peut plus se limiter à la simple négociation des conditions de travail au seul niveau de l'entreprise isolée. Face à certains problèmes qui touchent l'ensemble des salariés ou tous ceux qui œuvrent en un secteur donné, les centrales syndicales tentent de porter le débat au niveau politique et la négociation au secteur public en est l'occasion. Il s'ensuit une certaine politisation des rapports collectifs du travail qui est d'ailleurs partagée par l'interlocuteur c'est-à-dire, par l'employeurgouvernement. Dans ce contexte nécessairement conflictuel, il est certes normal que le mouvement des caisses s'interroge sur la qualité de ses liens avec le mouvement syndical et même, sur l'opportunité de privilégier de telles liaisons. Soulever pareilles questions ce n'est cependant pas y répondre mais peut-être, est-ce la meilleure façon d'en entreprendre l'étude positive. D'autre part, par ses services et ses obligations à l'endroit de sa clientèle, le mouvement des caisses peut parfois sembler se rapprocher d'assez près des banques. Peut-être que le mouvement syndical se pose-t-il à l'égard de ce mouvement coopératif à peu près ce même type de questions?

\title{
THE INFLUENCE OF PUBLIC OPINION ON LABOUR-MANAGEMENT RELATIONS AND DISPUTE SETTLEMENT
}

\author{
Stephen G. Peitchinis
}

«Industrial conflict», wrote A.W.R. Carrothers, «is a political event in which each contestant seeks to marshall public opinion in its favour, even though in the occasional dispute either side may profess its indifference to, or contempt for the moral force of public opinion. Further, in a dispute in the public sector, where a profit motive does not supply leverage for settlement, public opinion may have to be an initial sanction. ${ }^{1}$ How much influence does public opinion have on relations between labour and management and in the settlement of disputes between them? Are they influenced by what is reported through the media or by what they each determine to be the prevailing view of the public? Which public? Without doubt the parties have different publics or place different weights on the opinions of different groups of the public.

Since labour-management disputes affect different groups of the public differently, it may be appropriate to divide the public into two

* Peitchinis, S. G. Professor of Economics, Faculty of Social Sciences, University of Calgary.

1 A.W.R. CARROTHERS, "Industrial Relations in a New Environment, " The Conference Board Record, January 1973, p. 50. 
groups: participants and outsiders. ${ }^{2}$ In the «participants» group would be included those members of the public who are affected by the dispute, such as, users of the goods and services produced by the disputants, producers and users of goods and services whose production depends on the goods and services of the disputants, members of the families of disputants, workers laid off because of the dispute and their families, and those who sell to the disputants and to others whose incomes have been affected. The extent to which users will be affected and the extent to which they will press for a speedy settlement, will depend, of course, on the extent to which alternative sources of supply are available at the same price and with the same convenience. ${ }^{3}$

In the «outsiders» group would be included those members of the public who are not affected by the dispute, whether directly or indirectly, and who therefore, could not have any interest in the outcome of the dispute. To the extent that this group registers an opinion it may be motivated by moral, social and political considerations, rather than economic considerations or considerations related to the terms and conditions of work and relations between the disputing parties. In such cases, the question arises whether or to what extent should the parties take note of the opinions expressed by the group.

\section{THE ROLE OF PUBLIC OPINION IN THE CONCILIATION SYSTEM}

The foundation of the Canadian Conciliation System was based on the premise that public opinion will have considerable influence on the parties, particularly in relation to recommendations for the settlement of disputes by neutral third parties. The founder of the conciliation system, W. L. MacKenzie King wrote: «It is not to be supposed that, because findings of Compulsory Investigation are not enforceable under penalty, findings in such cases are without effect. Public Opinion, as an instrument of authority, may be more subtle and elusive than the power of Law visualized in penalties and prisons. $»^{4}$ But, the formation of public opinion that would exert such influence requires comprehensive information on disputes. Hence, in the original legislation emphasis was put on compulsory investigation on all matters related to disputes, including profits, prices, comparative wages and others, and the publication of all findings in The Labour Gazette. MacKenzie King wrote: "The Public has a right to be informed impartially on the merits of situations which threaten its well being. $\gg^{5}$

2 In an examination of «The Role of Public Opinion in Relation to the Mediator, "Edgar L. Warren divided the public into three groups: parties, participants and outsiders. Institute of Industrial Relations, University of California, Reprint No. 29, 1953, p. 1 .

3 Loc. cit.

4 W.L. MACKENZIE KING, Industry and Humanity, Houghton Mifflin, The University Press, Cambridge, 1918, pp. 219-220.

5 Ibid., p. 518. 
The emphasis appears to have changed in existing legislation from one of comprehensive investigation and report to the public-atlarge, to one of assisting the parties in the formulation of concessions and compromises, and providing them with an opportunity to ascertain what knowledgeable outsiders would consider reasonable bases for settlement. ${ }^{6}$ Although a report to the minister continues to be required, which is made available to the parties and eventually published, ${ }^{7}$ the primary role of the process has become normative and accommodative. This does not mean that conciliation boards no longer investigate issues relevant to a dispute; that reports of conciliation boards are no longer publicized; or that the normative and accommodative approaches of conciliation were not emphasized in the original legislation. It means rather that investigation and publicity are no longer emphasized to the extent necessary for the formation of an informed public opinion. Increasingly, administrators of Acts which govern labour-management relations view disputes as problems that concern primarily the two parties involved. The inconvenience imposed on the public is viewed as the price to be paid for having free collective bargaining.

Perhaps there is merit in putting more emphasis on the normative and accommodative approaches to conciliation and less on investigation, report and public opinion. Conciliators must now rely more on their diplomacy and expertise to bring the parties closer together and to agreement, and less on the force of public opinion. There were too many instances in the past in which conciliators seemed to rely on public opinion to cause parties to accept badly conceived, unacceptable recommendations.

\section{THE ATTITUDE OF LABOUR ORGANIZATIONS}

An examination of certain actions by labour organizations may convey the impression that on occassion they have demonstrated nothing but contempt for public opinion: illegal strikes, violence, mob actions, defiance of court orders and orders of parliament, disregard of appeals by public organizations and so on. But, in the context of the totality of labour-management contractual relationships, such instances are not as widespread as they are often made to be. A detailed examination of the strike record in Canada over the period 1900-1967 by Professor Stuart Jamieson established a number of periods during which strikes were accompanied by varying degrees of "violence and illegality.» In each period there were different reasons: in 1919-1920, the main reason appears to have been «resistance to change by employers and governments alike» which generated «attitudes of revolt

6 H.D. WOODS, Labour Policy in Canada, Macmillan of Canada, Toronto, 1973, p. 158.

${ }^{7}$ An indication perhaps of the change in emphasis is the decision to discontinue the publication of reports in The Labour Gazette. Although they continue to be published, this appears to be done for the record rather than to inform the public and provide a basis for the formation of public opinion. 
among workers, union and non-union alike; ${ }^{8}$ in $1946-47$ there was a general «blow-up» after the long period of "wartime restrictions and frustrations; ${ }^{9}$ and in 1965-66 a number of reasons appear to have existed, amongst which the main ones were, a lagging rate of economic growth and the resultant widespread layoffs, a rapid rate of technological change and the resultant fear of technological unemployment, and widespread dissatisfaction amongst workers with their own organizations and leadership. ${ }^{10}$ Had Professor Jamieson examined the violence and illegality of the period 1973-75 he would probably have found the main reasons to be frustration of public service employees in their efforts to get reluctant governments to negotiate terms and conditions of employment, temper tantrums associated with growing pains of some union leaders, and the erosive effects of rapidly rising prices.

Therefore, the record appears to suggest that strikes, with varying degrees of "violence and illegality,» are a periodic phenomenon in our society. Perhaps we need such behavioural manifestations from time to time as a sort of catharsis in social relations and in relations between labour and management. It is perhaps necessary to the development and long run stability of our democratic processes and institutions to challenge from time to time established and seemingly accepted rules, regulations, processes and procedures. Challenges compel the re-examination of the fundamental premises on which rules, regulations and procedures are based.

Workers who have participated in illegal strikes and engaged in some violent activities have viewed their actions as necessary challenges to rules, regulations and conditions which appeared to them unfair and unjust. Frequently they became agitated by what they believed to be unfair treatment from their employers, unduly restrictive legislation, unwarranted injunctions handed down by biased judges, and occasionally by a leadership lacking experience and courage. They knew that public opinion would not favour their actions, but could find no alternative ways to express forcefully their growing frustrations.

Workers have always had a strong reservation about the nature and strength of public opinion: they have often expressed displeasure at what they believed to be unfair and inaccurate reporting by the media, which misinformed the public and created a biased public opinion; secondly there has always existed a question about whose opinion is being communicated - the opinion prevailing amongst participant groups or the opinion of the outsider groups. Since the latter have traditionally had easier access to media instruments, there has always existed a suspicion that their opinion predominated. Thirdly, there has always prevailed a view amongst workers that the media

8 Stuart M. JAMIESON, Times of Trouble: Labour Unrest and Industrial Conflict in Canada, 1900-66, Study No. 22, Task Force on Labour Relations, Information Canada, Ottawa, 1971, p. 476:

$9 \quad$ Ibid., p. 455.

10 Ibid., pp. 467-471. 
are either controlled or influenced by their employers, and that therefore, it should be expected that they will attempt to bias public opinion in favour of the employer; and finally, since the public is not directly affected by many of the issues in dispute, it could not be expected to appreciate fully the need for the strong stand that workers occasionally take. This is what caused the president of the Canadian Union of Postal Workers to say «if the public cannot understand our viewpoint then the public be damned. ${ }^{11}$

These are legitimate reservations and concerns. But, in many instances the workers themselves are misinformed or inadequately informed. Often they are given information about terms and conditions of employment offered by employers, and about rules, regulations, procedures and on the nature of relations with employers and governments, that is designed to alienate rather than illuminate. The motives for inadequate or inaccurate information differ from instance to instance: inexperienced insecure leadership; dictatorial leadership using the big lie method; politically motivated leadership; control of the organization by agitators, serving special interests; and other.

Inadequate and inaccurate information introduces preconceived biases in the decision-making process and stacks the cards in favour of those who control the production and distribution of the information. To those who accept the information as being accurate and representative of the true situation, all other information is biased, and public opinion formulated on the basis of such biased information is by implication itself biased. This sort of reasoning makes the rejection of public opinion a justifiable action.

But, such reservations, suspicions, and alleged or established deficiencies in the system are a natural consequence of freedom and diversity. Their existence should not be interpreted to manifest a general disregard of public opinion. If public opinion did not matter in the conduct of labour-management relations, then the parties would not engage in efforts designed to influence it; yet, both of them allocate considerable time, effort and resources in pronouncements and advertisements designed to make the public understand and appreciate the reasonableness of their respective positions. In all probability, strikes in the public sector, particularly those of teachers, nurses, postmen, railway workers, non-medical hospital workers, and such other, would have lasted longer than they did, but for the force of public opinion. Similarly, decisions by federal and provincial governments to order the termination of strikes can be regarded as responses to public pressure.

But, perhaps the most telling demonstration of the influence of public opinion on the parties and on governments is what happens in

11 Joe DAVIDSON in response to reporter's question during the long period of protracted negotiations with the government in 1975. The statement was made during a television interview, before the strike that started in October 1975. 
the absence of clearly formulated public opinion: disputes tend to drag on and governments adopt a hands-off policy, regardless of the nature of service provided by the disputants. Presumably, if the public can do without the service over a prolonged period of time, or if the public can find partial or full substitutes for the service, even though costly and less convenient, it may become indifferent and let the dispute drag on. An example of this is provided by the October-November 1975 strike of the Canadian Union of Postal Workers. Over a period of five years preceding the strike, the postal service was interrupted so frequently, and became so erratic and unreliable, that the public developed a rather cynical attitude towards it. Government efforts to improve it through automation and the introduction of a postal code were being frustrated by the Canadian Union of Postal Workers, which had embarked upon a policy of confrontation and boycott. The long period of negotiation that preceded the strike were accompanied with pronouncements, threats and warnings by the union to the effect that a strike was inevitable unless the government gave in to its demands. The public was prepared to accept the strike and when the strike came it surprised no one. Indeed, as the strike dragged on the public seemed to develop a sense of indifference towards it, which contributed to its continuation. Had there been an outcry instead, the strike would have been terminated sooner, either by negotiation or compulsory arbitration. It can be concluded, therefore, that public opinion can contribute to the shortening or lengthening of disputes, depending on whether it is respectively strongly negative or indifferent.

Finally, a few comments on the seeming indifference of the public at large - both participant groups and outsider groups - to the evident increase in the number of the labour-management disputes in recent years. Had the public taken greater interest in what has been happening, and had it expressed concern, perhaps the parties would not have taken decisions as readily as they have to disrupt production processes, and governments would not have treated the problem in as cavalier a manner as they have done. Furthermore, the possibility must be considered that public indifference itself contributes to the rate of frequency as well as to the duration of disruptive disputes.

Given this possibility, the question arises what would cause the public to become indifferent to a dispute? The availability of alternative sources of goods and services or substitutes to the disrupted supply of goods and services, would be one reason; another would be the availability of secondary alternative sources of income for workers involved in the dispute, workers affected by the dispute and their families earnings of other family members, strike pay, unemployment insurance, welfare, savings, loans; and still another would be lack of adequate information. The amount and nature of information made available to the public about individual disputes is frequently so inadequate as to preclude the possibility of forming an informed public opinion. Even on major disputes, such as the one between the Post Office and the Canadian Union of Postal Workers, the issues were not given the degree of detailed and widespread publicity that would be necessary for the expression of public opinion. The information that the public was given 
related to some of the major issues, such as the question of automation, the question of part-time workers, the question of over-time, the question of pay, but not the nature of difficulties encountered in reaching an agreement. The public cannot be expected to form an opinion on what would constitute a reasonable basis for settlement, without information on the nature of positions taken by the parties and the nature of arguments they present in support of their respective positions.

If public opinion is to be restored to a position of influence in the settlement of labour-management disputes the scope and practice of conciliation proceedings should be expanded to include the compulsory investigation and publication of all issues related to the disputes, such as profits, prices, costs, competition, restrictive practices, comparative wages and other terms and conditions of employment, and other. In addition, the investigating commissioners and boards should have the power to publicize the respective positions and arguments presented by the parties. The most effective publicity would be provided, of course, by open forum investigations: let the parties argue the merits of their positions and let the public determine what would constitute a reasonable basis for settlement. «For Public Opinion to be effective» wrote MacKenzie King «it is necessary that it be made an informed Opinion.» This is why he put the emphasis on the investigative role of the conciliation process. He believed that if conciliation boards were to examine and comment on profits, prices as well as on wages, the result will be «an intelligently formed Public Opinion. ${ }^{12}$

\title{
LA CONSULTATION : UN PROCESSUS ANDRAGOGIQUE CENTRÉ SUR LE CLIENT
}

\author{
Hubert Wallot
}

L'amélioration de la productivité ainsi qu'une élémentaire politique de personnel dans une entreprise suggèrent que l'on se préoccupe de la formation continue des travailleurs de cette entreprise. plus particulièrement, dans le propos qui nous concerne ici, des cadres.

À une époque où existe une inflation dans le secteur de l'éducation dispensée sur une base formelle et où la demi-vie du savoir est accélérée, je suggère l'idée de considérer l'usage de consultants comme un mécanisme approprié d'éducation continue en administration pour les années à venir, et également comme un processus d'apprentissage bilatéral pour le consultant et le client. En premier lieu, je considérerai les formes traditionnelles d'éducation continue dans l'entreprise. En second lieu, je considérerai le concept de consultant; en troisième lieu; je discuterai de la compatibilité ou non d'un tel concept avec les hypothèses

12 Ibid., pp. 314 and pp. 515-516. 